\title{
BAHASA, BUDAYA, DAN IDENTITAS ORANG JEPANG \\ DALAM NOVEL 47 RONIN KARYA JOHN ALLYN
}

\author{
Liastuti Ustiningsih (Corresponding Author) \\ Fakultas Bahasa dan Sastra Universitas Kanjuruhan Malang \\ Jl. S. Supriyadi 48 Malang, Indonesia \\ Phone: (0341) 801488 (ext:341) E-Mail:
}

\begin{abstract}
Abstrak: Di antara banyaknya nilai-nilai tradisional Jepang yang berakar dari budaya luhur mereka, terdapat beberapa hal yang menarik untuk dipelajari seperti konsep chu, ko, giri, ninjou, gimu, dan on. Nilai-nilai itulah yang kemudian dianggap sebagai ciri khas atau identitas bangsa Jepang. Sebuah identitas yang membangun bangsa Jepang sehingga menjadi bangsa besar seperti sekarang ini.

Nilai-nilai tersebut tidak hanya tercermin dalam kehidupan sehari-hari masyarakat Jepang, namun juga dalam wujud karya seni. Salah satu contohnya adalah novel "Kisah 47 Ronin" karya John Allyn. Novel ini adalah jenis novel fiksi sejarah yang ditulis berdasarkan peristiwa yang pernah terjadi di Jepang pada tahun 1703, dimana empat puluh tujuh ronin yang dipimpin oleh Oishi kuranosuke Yoshitaka menyerang rumah kediaman pejabat tinggi istana Kira Kozuke no Suke Yoshihisa guna membalas dendam kematian majikan mereka yang bernama Asano Takumi no Kami.

Salah satu budaya Jepang yang akan dibahas dalam penelitian ini adalah budaya on dan giri yang tercermin dalam bahasa didalam karya novel Kisah 47 Ronin karya John Allyn.

On adalah nilai-nilai penting yang harus dipertahankan di dalam kehidupan masyarakat Jepang yang berkaitan dengan adanya jaringan hubungan kewajiban yang saling timbal balik. Karena adanya rasa berhutang budi, maka orang Jepang merasa berkewajiban untuk membalas budi baik kepada orang tua, penguasa, masyarakat, dan negara.

Giri adalah hutang yang harus dibayar atau dilunasi dengan perhitungan yang pasti atas suatu kebajikan yang telah diterima oleh seseorang dan kebajikan itu harus dibayar yang mempunyai batas waktu tertentu.
\end{abstract}

Kata Kunci: On, giri, Novel 47 Ronin 


\section{Latar Belakang}

Ada pepatah kuno mengatakan bahwa "suatu bangsa di atas dapat dikenali dari bahasanya". Memang benar kata pepatah di atas untuk mengetahui seseorang berasal dari bangsa mana,salah satunya mengenali bahasa yang digunakannya. Bahasa tidak bisa lepas dari identitas kultural seseorang. Suatu bangsa memiliki ciriciri yang dapat diidentifikasi dari aspek bahasa, pakaian, tradisi, dan adat istiadat. Diantara kelima komponen kebangsaan yaitu wilayah, negara, bahasa, kebudayaan, dan sejarah, maka bahasa adalah unsur terkuat pembentuk identitas. Bahasa sebagai alat terpenting komunikasi antarmanusia adalah senjata paling ampuh untuk mempersatukan atau memecah belah sebuah bangsa. Bahasa adalah identitas sebuah bangsa.

Dari aspek bahasa sebagai identitas suatu bangsa, bangsa Jepang adalah contohnya. Bangsa Jepang bukannya anti budaya asing, mereka hanya ingin mempertahankan identitas mereka sebagai "bangsa Jepang". Masyarakat Jepang hanya menggunakan bahasa Jepang sebagai alat berkomunikasi. Semua marka jalan menggunakan huruf kanji, hiragana, atau katakana. Hampir semua portal berita, petunjuk wisata, dan penjelasan di museum disampaikan dalam bahasa Jepang.

Sedikit sekali orang Jepang yang bisa bahasa Inggris. Sebegitu cintanya penduduk Jepang dengan bahasanya sendiri hingga hampir tidak memberikan ruang bagi orang asing. Namun kondisi seperti ini sesungguhnya membuat orang asing menghormati bangsa Jepang yang mencintai budayanya sendiri. Bahasa dan budaya itu satu paket. Orang yang belajar bahasa asing biasanya turut mempelajari kebudayaan yang bersangkutan. Orang asing yang belajar bahasa Jepang pasti akan belajar pula tentang kebudayaan Jepang.

Di antara banyaknya nilai-nilai tradisional Jepang yang berakar dari budaya luhur mereka, terdapat beberapa hal yang menarik untuk dipelajari seperti konsep chu, ko, giri, ninjou, gimu, dan on. Nilai-nilai itulah yang kemudian dianggap sebagai ciri khas atau identitas bangsa Jepang. Sebuah identitas yang membangun bangsa Jepang sehingga menjadi bangsa besar seperti sekarang ini. 
Nilai-nilai tersebut tidak hanya tercermin dalam kehidupan sehari-hari masyarakat Jepang, namun juga dalam wujud karya seni. Salah satu contohnya adalah novel "Kisah 47 Ronin" karya John Allyn. Novel ini adalah jenis novel fiksi sejarah yang ditulis berdasarkan peristiwa yang pernah terjadi di Jepang pada tahun 1703, dimana empat puluh tujuh ronin yang dipimpin oleh Oishi kuranosuke Yoshitaka menyerang rumah kediaman pejabat tinggi istana Kira Kozuke no Suke Yoshihisa guna membalas dendam kematian majikan mereka yang bernama Asano Takumi no Kami.

Novel ini adalah sebuah novel best-seller bahkan sudah dibuatkan filmnya. Kandungan filosofi dalam novel ini sarat berbicara tentang hutang budi yang harus dan wajib dibayar, menjaga nama baik, kewajibankewajiban yang harus dijalankan dalam hubungan manusia. Artinya jika seseorang telah menerima sesuatu kebaikan dari orang lain, maka ia harus membalas kebaikan itu walaupun tindak balasan itu dilakukan dalam jangka waktu yang lama.

Salah satu budaya Jepang yang akan dibahas dalam penelitian ini adalah budaya on dan giri yang tercermin dalam bahasa didalam karya novel "Kisah 47 Ronin" karya John Allyn.

\section{Tinjauan Pustaka}

\section{Konsep On}

Bagi orang Jepang, on merupakan perasaan berhutang yang paling utama dan selalu ada dalam kehidupan manusia (Benedict, 1992:121). Dengan kata lain, on adalah nilai-nilai penting yang harus dipertahankan di dalam kehidupan masyarakat Jepang yang berkaitan dengan adanya jaringan hubungan kewajiban yang saling timbal balik. Karena adanya rasa berhutang budi, maka orang Jepang merasa berkewajiban untuk membalas budi baik kepada orang tua, penguasa, masyarakat, dan negara.

On merupakan istilah yang digunakan untuk menunjuk kepada hutang psikologis dan sosial yang dikenakan kepada seseorang atas penerimaan-penerimaan atau kebaikan yang diterimanya dari orang lain. On diartikan sebagai hutang budi, kewajiban, atau kemurahan hati. Seseorang dikatakan menerima on apabila ia menerima anugerah, pemberian, atau kemurahan hati dari 
pemberi on. Keluarga sebagai basis utama dari sebuah struktur masyarakat merupakan tempat pertama dimana kesadaran-kesadaran mengenai hutang dan kewajiban untuk mengembalikannya ditanamkan dengan begitu kuat. Setiap anggota keluarga secara turun-temurun diajarkan mengenai pentingnya menyadari on yang telah mereka terima dari orang tua, nenek moyang, dan negara.

Konsep on bersifat hirarkis dalam arti kedudukan pemberi dan penerima on tidak sederajat. Pemberi on selalu memiliki posisi yang lebih tinggi daripada penerima. Contoh yang paling umum dipergunakan untuk menggambarkan hubungan yang melibatkan on adalah hubungan antara orang tua dan anak. Orang tua memberikan kebutuhan yang bersifat material, perlindungan, keamanan, cinta dan kasih saying serta upaya untuk mensosialisasikan si anak. Di lain pihak, si anak menerima semua pemberian tadi pada seluruh masa kehidupannya. Dengan kata lain, on adalah istilah yang menunjuk kepada hutang psikologis maupun sosial yang dikenakan kepada seseorang atas penerimaan-penerimaan, anugerah atau pemberian dengan proporsi yang utama.

Pemberian-pemberian itu secara hukum tidak memerlukan balasan, tetapi pada kenyataannya perasaan berhutang yang dirasakan bagi penerima on sangat kuat sehingga walaupun secara hukum ia tidak dituntut untuk membalas pemberiannya yang telah diterima, namun secara moral hal itu merupakan suatu kewajiban yang harus dilaksanakan. Pengembalian on yang telah diterima disebut gimu. Bagi orang Jepang, upaya untuk membayar kembali sebuah hutang (melaksanakan gimu) merupakan sebuah kebajikan.

Kewajiban yang bersifat sepihak dan tak kenal batas dari on ini diperkuat dengan indoktrinasi yang sistematis yang dilakukan oleh masyarakat, dimana setiap individu secara keras ditekan untuk selalu memperhatikan hal-hal yang berhubungan dengan hutang dan rasa terima kasih. Pelanggaran terhadap norma-norma yang berhubungan dengan hal di atas mengandung sanksi sosial yang cukup berat. Seseorang yang melalaikan pembayaran kembali on yang telah diterimanya disebut on shirazu yaitu 
orang yang tidak tahu balas budi. Sebutan on shirazu yang diberikan kepada seseorang merupakan sesuatu yang dinilai sangat buruk, dan dianggap sebagai penghinaan bagi orang tersebut. Seseorang yang disebut on shirazu pada akhirnya akan dijauhi serta dikucilkan oleh masyarakat.

\section{Konsep Giri dan Ninjo}

Giri menurut Mattuladadalam Nur Afni (2005:3) adalah rasa berkewajiban untuk membalas sikap atau kebaikan yang telah diterima dari orang lain, yang setimpal. Giri adalah hutang yang harus dibayar atau dilunasi dengan perhitungan yang pasti atas suatu kebajikan yang telah diterima oleh seseorang dan kebajikan itu harus dibayar yang mempunyai batas waktu tertentu.

Giri secara harafiah diartikan sebagai kewajiban moral, yang merujuk kepada kepada kewajiban-kewajiban sosial yang bersifat normatif dan etis yang menghendaki orang Jepang untuk berperilaku sesuai dengan apa yang diharapkan oleh masyarakat dalam berhubungan dengan individu dimana seseorang menjalin hubungan yang khusus. Menurut Benedict, giri memiliki dua pembagian yang jelas yaitu:

1. Giri kepada dunia yaitu kewajiban membayar kembali on kepada semuanya.

2. Giri kepada nama sendiri yaitu kewajiban untuk tetap menjaga nama serta reputasi.

Giri adalah kewajiban untuk mengembalikan atau membalas semua pemberian yang pernah diterima. Konsep giri berhubungan erat dengan konsep on dan gimu yang telah dijelaskan terlebih dahulu. Perbedaannya, giri tak hanya berlaku antar dua pihak yang memiliki status yang berbeda, tetapi bisa juga berlaku diantara orang yang memiliki status sederajat seperti antar teman, tetangga, dan relasi-relasi. Pemenuhan kewajiban giri yang kurang dari nilai yang telah diterima menyebabkan seseorang dicap sebagai orang yang tidak tahu giri, sedangkan pengembalian yang melebihi dari apa yang telah diterima sama dengan memaksa orang lain memikul on. Jadi giri merupakan kewajiban untuk mengembalikan semua kebaikan yang pernah diterima seseorang dari orang lain dengan nilai yang sama. 
Konsep lain yang seringkali diletakkan secara kontras dengan giri yaitu ninjo. Berbeda dengan giri yang merupakan kewajiban moral untuk melakukan tindakan saling berbalasan, ninjo adalah kecenderungan, perasaan, dan keinginan alamiah manusia yang tidak terkait dengan norma-norma seperti halnya giri. Apabila giri bersifat moral dan sosial, maka ninjo bersifat psikologis dan personal.

Merupakan suatu hal yang alamiah bahwa giri dan ninjo akan menjadi konflik yang terjadi sepanjang waktu, dan di Jepang, giri seringkali didahulukan sebelum ninjo. Perasaanperasaan manusiawi yang dimiliki seseorang kadangkala bertentangan dengan norma-norma sosial yang terdapat dalam masyarakat. Seorang samurai yang rela mengorbankan anak atau seluruh keluarganya untuk membela tuannya, berada dalam posisi sulit dimana ia harus menentukan antara melaksanakan giri atau menuruti ninjo. Di satu sisi, perasaan manusiawinya menghendaki dia melindungi dan mempertahankan kehidupan keluarganya, namun di sisi lain normanorma sosial mendesaknya untuk mendahulukan giri di atas perasaan manusiawinya.

Dalam keadaan dilematis ini, seseorang tidak diberi pilihan untuk dapat mengambil keputusan yang memuaskan semua pihak. Oleh karena itu, untuk mengatasinya ada tiga alternative yang dikemukakan oleh Harumi Befu (

1. Menekan perasaan sendiri dan memilih untuk menghormati prinsip nilainilai masyarakat.

2. Menutup mata dari kewajiban-kewajiban moral yang ada dan mengikuti perasaan manusiawinya sendiri.

3. Melakukan bunuh diri karena tidak mampu mengesampingkan baik keinginan pribadi, maupun kewajiban moralnya kepada masyarakat.

\section{METODE PENELITIAN}

Pendekatan yang digunakan dalam penelitian ini adalah pendekatan kualitatif dengan jenis penelitian deskriptif. Penggunaan pendekatan kualitatif dengan jenis pendekatan 
deskriptif dalam penelitian ini, karena peneliti bermaksud untuk memberikan penafsiran dan mendeskripsikan keadaan objek yang telah ditentukan dengan menggunakan karya sastra sebagai sumber data yang dianalisis. Sedangkan hasil analisis (data) yang disajikan berbentuk deskriptif secara objektif tentang nilai-nilai moral on dan giri dalam masyarakat Jepang. Data tersebut bukanlah berupa angka-angka hasil perhitungan statistik atau koefisien tentang hubungan suatu variabel.

Data yang akan dipaparkan dalam penelitian ini adalah kalimat-kalimat dan paragraf-paragraf dari kutipan cerita dalam novel "Kisah 47 Ronin" karya John Allyn. Sumber data yang digunakan dalam penelitian ini adalah novel "Kisah 47 Ronin" karya John Allyn.

Model analissis data yang digunakan dalam penelitian ini adalah model analisis interaktif-dialektik atau bolak-balik menurut keperluan dan kecukupan. Dengan teknik tersebut analisis data dilakukan secara melingkar, serempak atau sekaligus, berulang-ulang, dan bolak-balik (menurut kebutuhan) dengan focus wacana novel "Kisah 47 Ronin" dalam rangka memperoleh penghayatan dan pemahaman makna yang mendalam terhadap pesan moral on dan giri yang direpresentasikan oleh novel "Kisah 47 Ronin".

Hal ini berarti dalam proses pengumpulan data, secara serempak peneliti mereduksi dan menyajikan data sebelum menganalisis data untuk memperoleh kesimpulan akhir mengenai pesan moral on dan giri dalam novel "Kisah 47 Ronin". Jika simpulannya dipandang kurang memadai, maka peneliti wajib mengulang kembali proses pengumpulan data dan analisis data sampai memperoleh simpulan akhir yang sesuai.

Adapun langkah-langkah analisis data meliputi (1) pembacaan secara kritis-kreatif terhadap sumber data dalam rangka memperoleh penghayatan dan pemahaman hermeneutif terhadap sumber data; (2) identifikasi data, data yang sudah diperoleh diberi kode sesuai dengan masalah penelitian; (3) pereduksian secara fenomenologis-editis terhadap data dalam rangka memperoleh data yang benar-benar hakiki untuk menjawab masalah penelitian; 
penyajian data yang terdiri atas identifikasi dan klasifikasi data berdasarkan masalah penelitian; (5) penafsiran data secara hermeneutic, dan (6) penyimpulan data.

\section{HASIL DAN PEMBAHASAN}

\section{On dan Giri dalam Masyarakat}

\section{Jepang}

Masyarakat adalah orang yang hidup bersama dan memiliki suatu aturan atau norma-norma yang berlaku yang dijadikan sebagai konsep moral untuk melaksanakan hidup. On dan giri merupakan etika yang mendasari perilaku dalam interaksi sosial orang Jepang. Konsep on dan giri merupakan nilai yang mengatur agar masyarakat secara psikologis berpikir dan bertindak sesuai dengan yang diinginkan oleh sesamanya. Mereka diharapkan untuk mengerti arti hutang budi, dan membalas kebaikan hati dan atau pemberian yang telah mereka terima sebagai tanda balas budi dan terimakasih.

On adalah nilai-nilai penting yang harus dipertahankan di dalam kehidupan masyarakat Jepang yang berkaitan dengan adanya jaringan hubungan kewajiban yang saling timbal balik. On adalah memikul beban tanggung jawab secara sosial dan psikis terhadap penerimaan kebaikan dari orang lain. Jika ditulis dengan huruf kanji, ON-nya ONKEI. Awalnya kata ini lahir ketika sang Samurai memberikan tanah kepada pengikutnya dalam masyarakat feodal. Orang atas menjembatani masalah umum dan pribadi orang bawah, serta orang atas lebih banyak memperhatikan orang bawah. Sebagai gantinya, orang bawah merasa berterimakasih dan menghormati orang atas, sehingga timbul kecenderungan respek atas loyalti. Dengan demikian, jika melupakan kebaikan (on) orang lain, secara moralitas hal ini tidak dimaafkan. Namun, on ini sama halnya dengan perasaan sentimen tradisi Jepang lainnya yang sedikit demi sedikit cenderung menipis.

Giri bisa diartikan sebagai kewajiban sosial yaitu sebuah kewajiban yang bersifat etis dan moral yang mengharuskan orang Jepang untuk bersikap seperti yang diharapkan oleh masyarakat dalam hubungan dengan individu-individu lain, dengan siapa seseorang menjalin hubungan yang istimewa atau khusus. 
Konsep emosi dan moral Jepang cukup sulit diterjemahkan ke dalam bahasa Inggris ataupun bahasa Indonesia. Demikian juga dengan "GIRI" yang sama sekali berbeda konsep dalam bahasa Inggris (karena beda budaya). Dalam masyarakat feodal, konsep giri yang terbentuk adalah dalam hubungan interaksi manusia (buruh dan majikan, orang tua dan anak, suami-isteri, kakak-adik, persahabatan, bahkan musuh atau lawan serta tempat bekerja) yang merupakan skala terpenting. Jelas sekali bahwa dalam hubungan timbal balik tersebut, rasa simpati, belas kasih pada orang yang menerima on ini terkadang sampai mengorbankan diri untuk mewujudkan rasa kebahagiaan/ kegembiraan mereka (balas jasa).

Secara kongkrit, giri ini muncul dan menjadi adat istiadat dalam masyarakat Jepang, misalnya: wujud dalam kabar berita (surat, kartu tahun baru, dsb), pemberian hadiah (hadiah akhir tahun/oseibo, tengah tahun/chuugen) yang dilakukan secara sukarela dan tulus ikhlas. Hal ini merupakan suatu dukungan atau bantuan kepada seseorang, tanpa memperhatikan untung-rugi ketika orang tersebut dilanda penderitaan atau dalam situasi sulit.

Masyarakat Jepang dituntut untuk mengerti serta melaksanakan konsep on dan giri di dalam kehidupannya. Kepribadian dan karakter moral masyarakat Jepang dibentuk sedari mereka kecil. Prinsip moral yang mereka anut berasal dari kebudayaan samurai Jepang yang terdiri dari empat elemen moral yaitu on, giri, gimu, dan ninjo.

On berarti rasa hutang budi. Dengan prinsip ini, seseorang akan merasa berhutang setiap kali orang lain berbuat baik padanya. Jika seseorang berbuat baik kepada kita, maka kita merasa harus membalas kebaikannya tersebut. Gimu berarti kewajiban. Jika seseorang berhutang budi, maka kita akan berkewajiban untuk membayarnya. Giri adalah kebaikan. Dengan prinsip ini, seseorang akan membantu temannya atau keluarganya semampunya. Jika kita mempunyai teman dekat dan dia butuh pertolongan, maka kita akan membantunya dengan cara apapun. Ninjo adalah rasa kasih sayang. Prinsip ini mengajarkan rasa empati terhadap sesama. Dengan prinsip ini, seseorang akan merasa semua 
manusia adalah satu dan sama, di bawah perbedaan yang telah diatur oleh karma.

Menurut Masakatsu, staf ahli Konsulat Jenderal Jepang di Jakarta, bahwa empat unsur ini adalah semacam kewajiban sosial yang harus dimiliki oleh setiap rakyat Jepang. Masakatsu menjelaskan bahwa sekolah dasar di Jepang

tidak mengajarkan pelajaran agama, hanya pelajaran moral satu jam setiap minggunya. Kendati demikian, empat prinsip moral tersebut terbentuk di lingkungan sekitar seorang anak. "Konsep ini memang tidak diajarkan di sekolah, namun diterima dan dipraktekkan langsung dari lingkungan," kata Masakatsu

\section{On dalam Novel 47 Ronin}

On diartikan sebagai hutang budi, kewajiban, atau kemurahan hati. Seseorang dikatakan menerima on apabila ia menerima anugerah, pemberian, atau kemurahan hati dari pemberi on. Keluarga sebagai basis utama dari sebuah struktur masyarakat merupakan tempat pertama dimana kesadaran-kesadaran mengenai hutang dan kewajiban untuk mengembalikannya ditanamkan dengan begitu kuat. Setiap anggota keluarga secara turun-temurun diajarkan mengenai pentingnya menyadari on yang telah mereka terima dari orang tua, nenek moyang, dan negara.

Konsep on bersifat hirarkis dalam arti kedudukan pemberi dan penerima on tidak sederajat. Pemberi on selalu memiliki posisi yang lebih tinggi daripada penerima.

Kutipan hal 13-14.

"karena kami setia pada ayahmu sehingga kami tak berpikir untuk mempermalukan beliau dengan melanggar perintah pemimpinnya yaitu shogun."

"Alasan Shogun Tsunayoshi memberlakukan undang-undang itu karena dia sangat ingin punya anak. Kau tahu, dia pernah kehilangan seorang anak putranya yang berusia empat tahun meninggal dunia. Dan pendetanya mengatakan bahwa untuk bisa punya putra lagi, dia harus bertobat - mungkin dia pernah menghilangkan nyawa beberapa makhluk hidup. Kau sudah tahu kalau kita tidak lagi menggunakan anjing dalam pertandingan - itu karena shogun dilahirkan pada Tahun Anjing, Sekarang membunuh anjing akan dihukum mati."

Kutipan di atas merupakan percakapan antara Oishi dan putrid Lord Osano. Oishi adalah kepala samurai Klan 
Asano. Nama lengkapnya adalah Oishi

Kuranosuke, sedangkan Lord Asano adalah seorang daimyo yang menguasai wilayah Ako. Daimyo berarti orang yang memiliki pengaruh besar di suatu wilayah. Di dalam masyarakat samurai di Jepang, istilah daimyō digunakan untuk samurai yang memiliki hak atas tanah yang luas (tuan tanah) dan memiliki banyak samurai sebagai pengikut.

Pada kutipan tersebut, digambarkan bahwa Oishi, sebagai seorang bawahan dari Lord Osano sangat menghormati pemimpinnya. Dia bahkan rela mati mempertaruhkan nyawanya demi pemimpinnya itu. Lord Asano sudah seperti adiknya (hal. 56).

"Oishi mengenang bahwa selain sifat pemarah, tak ada daimyo lain yang lebih layak dari dia di seluruh Jepang. Bagian wilayah ini dikenal karena kesetiaan mereka pada keluhuran tradisi samurai dan tak seorang pun yang lebih murah hati, lebih berani dan lebih sungguhsungguh berusaha mewujudkan pemikiran itu selain Lord Asano. Ia akan mengikuti majikan yang seperti itu, bila perlu sampai mati. Ia takkan ragu menarik pedang dan bergabung dengan majikannya saat ini juga jika itu dapat menyelesaikan segalanya." (hal. 68)
"Bila waktunya tiba dimana ia perlu bunuh diri, ia siap." (hal. 68)

Lord Asano menghargai segala peraturan yang dibuat oleh Shogun Tsunayoshi karena sebagai daimyo yang merupakan bawahan dari shogun dia wajib mentaati semua peraturan yang dibuat atasannya yaitu Shogun Tsunayoshi.

Shogun

Tsunayoshi adalah shogun ke-5

dari Keshogunan Tokugawa di Jepang. Ia adalah putra dari Tokugawa Iemitsu, adik bungsu dari Tokugawa Ietsuna, cucu dari Tokugawa Hidetada dan cicit dari Tokugawa Ieyasu. Tsunayoshi dikenal karena membuat undangundang perlindungan hewan, khususnya untuk anjing. Karena itulah ia dijuluki sebagai "shogun anjing".

Dalam novel "47 Ronin" ini menceritakan tentang kesetiaan para samurai kepada tuannya daimyo. Daimyo memberi tempat tinggal, kedudukan, pangkat, dan kehidupan yang baik kepada para samurai dan keluarganya. Sebagai pengikut ajaran Kong $\mathrm{Hu} \mathrm{Cu}$ dan juga sebagai seorang samurai yang telah menerima on, mereka wajib membayar on itu dengan 
cara kesetiaan, mengabdi, atau balas dendam.

"Kesetiaanmu adalah kepada keluarga Asano. Tugas utama kita yaitu mengikuti perintah saudara majikan kita dan pewaris sah atas wilayah ini.... Tidakkah Kong Hu Cu juga berkata bahwa dari lima kebajikan, kesetiaan mendahului kewajiban moral yang lain?"

"Tak ada yang perlu diragukan tentang kesetiaan. Kami semua setia. Satu-satunya pertanyaan adalah bagaimana kita dapat menunjukkan kesetiaan dengan cara yang terbaik. Dan menurutku, jika kita tidak balas dendam, maka kita akan dianggap pengecut dan lemah!” (hal. 77)

"atas apa yang baru saja kau katakana pada pemimpin kita. Tak ada alasan untuk meragukan kesetiaannya. Dengan tidak menunjukkan perlawanan dan menaati perintah shogun, kita akan mendapatkan lebih dari apa yang akan kita peroleh melalui pertarungan." (hal.78)

"Kemana pun kalian pergi, apa pun yang kalian lakukan, ingatlah bahwa di benakku dan di benak pemimpin kita kalian selalu menjadi samurai Klan Asano. Selalu bertindak yang dapat menjadi penghormatan bagi keluarga ini. Aku tahu Lord Asano senantiasa menjaga kalian semua seperti aku juga tahu dia selalu menjagaku. Mari kita buat arwahnya bahagia - tidak sedih." (hal. 96)
Kaum samurai sebagai golongan yang disegani adalah kaum prajurit yang mengabdikan hidupnya untuk majikan. Ajaran Bushido yang merupakan pedoman bagi samurai banyak mengajarkan mengenai kepatuhan, pengabdian serta kesetiaan dalam mengabdi. Bushido adalah ajaran yang terdapat pada Budha Zen, yang dapat diartikan sebagai kode etik para samurai. Kode etik ini meliputi kepatuhan, kesetiaan, tanggung jawab, kesederhanaan serta keberanian untuk mati. Kepercayaan terhadap Reinkarnasi atau keyakinan bahwa orang yang telah meninggal akan terlahir kembali, menjadikan samurai tidak pernah takut menghadapi kematian. Pengabdian kesetiaan samurai melebihi batas antara hidup dan mati.

Sebagai seorang yang menerima on, para penerima on wajib mengesampingkan masalah pribadinya, seperti kutipan berikut ini.

“...tapi seperti biasa, Oishi
selalu mengenyampingkan
perasaan pribadinya. Dengan
sabar dia menjelaskan bahwa
kehormatan keluarga majikan,
mereka adalah yang utama...."
(hal. 142)




\section{Giri dalam Novel 47 Ronin}

Giri pertama kali muncul pada masyarakat agricultural, masyarakat dengan sistem feodal. Secara garis besar giri didefinisikan sebagai salah satu cara pengembalian on yang terdiri atas serentetan beban kewajiban mulai dari rasa terima kasih atas perbuatan baik yang diterima dahulu hingga tugas balas dendam. Sedangkan dalam kamus bahasa Jepang sendiri giri diterjemahkan sebagai jalan yang benar, jalan yang seharusnya diikuti oleh manusia, sesuatu yang dilakukan dengan penuh keengganan untuk memenuhi permintaan maaf terhadap dunia.

Novel "Kisah 47 Ronin" karya John Allyn memiliki latar belakang zaman feodal tepatnya di awal abad ke18 tahun 1701. Pada masa itu, Jepang di pimpin oleh seorang Shogun yang bernama Tokugawa Tsunayoshi (hal. 12-15). Shogun mengeluarkan peraturan Undang-Undang Pelestarian Hidup yang melarang membunuh binatang, sehingga banyak tanah pertanian yang tidak terawat baik.

Giri terbagi menjadi dua yaitu (1) Giri terhadap dunia, dan (2) Giri terhadap nama. Giri terhadap dunia yaitu kewajiban seseorang untuk membayar on kepada sesamanya, umumnya hubungannya bersifat kontrak. Contoh : kewajiban terhadap keluarga mertua, kewajiban terhadap majikan/rekan sekerja (misal : tuan tanah atau sesama prajurit), kewajiban terhadap kerabat, kewajiban terhadap nenek moyang dll.

"Aku setuju kalau Kira harus mati, ... tak ada yang lebih kuinginkan selain menyerang dia sekarang juga."

Kira adalah seorang pemimpin upacara di istana Shogun Tsunayoshi, orang yang sangat tidak disukai oleh Lord Asano karena suka meminta suap kepada para daimyo. Lord Asano mati karena bertempur dengan Kira. Sebagai anak buah dari Lord Asano, para samurai wajib membalas kematian majikannya itu.

Contoh kesetiaan samurai kepada majikannya yang terdapat pada Novel 47 Ronin ini mengenai pembalasan dendam mantan samurai atas kematian majikan mereka. Kisah ini terjadi di wilayah Ako di Jepang. Kisah pembalasan dendam para Ronin dilakukan untuk membalaskan dendam majikan mereka yang telah meninggal. Balas dendam ini dilakukan karena Kira 
Kozuke No Suke, sebagai pejabat Ako telah melukai Asano Takumi. Balas dendam Ronin merupakan pengabdian kepatuhan mereka terhadap Asano Takumi Naganori. Ini dikarenakan Asano adalah majikan para Ronin. Balas dendam Ronin dipimpin oleh Oishi Kuranosuke Yoshitaka adalah kepala samurai klan Asano. Maka balas dendam Ronin dipimpin oleh Oishi. Oishi dan anak buahnya memenggal kepala Kira dan meletakkan kepala musuh majikan mereka di atas makam Asano. Balas dendam yang dilakukan mereka telah berhasil. Setelah berhasil melakukan balas dendam para Ronin melakukan Junshi dengan cara seppuku. Hal ini dilakukan untuk mengikuti kematian Asano. Perilaku Junshi yang dilakukan ke 47 Ronin adalah sikap pertanggung jawaban dan keberanian untuk membuktikan kesetiaan para Ronin kepada Asano.

Giri terhadap nama sendiri adalah kewajiban untuk menjaga kebersihan serta reputasi seseorang dari fitnah. Contoh giri yang dilakukan sebagai kompensasi atas kebaikan yang diterima oleh Jepang dari Cina setelah perang dunia ke II.
"Apa maksudnya bicara seperti itu?" serunya sambil melangkah ke pintu dapur.

"Jangan, tunggu," kata Lord Asano pelan namun berwibawa.

"Tapi menghina pelayan anda berarti menghina anda" Hara bersikeras. "Setidaknya aku potong lidahnya, bila anda tidak mengijinkan aku memenggal kepalanya."

Kutipan di atas menunjukkan kewajiban seorang bawahan untuk menjaga nama baik atau reputasi tuannya. Hara adalah seorang samurai dari Lord Asano. Dia tidak terima ketika ada seorang pelayan menghina tuannya dengan suara yang keras.

“....Kau harus berhati-hati pada Kira. Dia menikmati kepercayaan Shogun dan seolah dia orang yang setia, tapi sebenarnya dia suka meminta suap serta memanfaatkan jabatannya. Tampaknya hanya ada satu cara bila berurusan dengan orang seperti itu, yaitu ikut dalam permainannya, tapi aku menolak cara seperti itu meskipun Kira selalu menyulitkan aku. Tapi, tak peduli apa yang terjadi, aku takkan membayar jasanya yang sudah seharusnya disediakan Shogun. Mungkin ini sikap keras kepala, tapi sepengetahuanku, ini sikap terhormat yang harus dilakukan para samurai. Mungkin aku takkan bisa mengembalikan kemerosotan yang telah melingkupi istana, tapi setidaknya 


\section{JIBS}

aku akan berusaha bertahan semampuku." (hal. 25)

Kutipan di atas menunjukkan sikap Lord Asano yang tidak mau memberi suap kepada Kira, seorang pembesar istana yang sangat dekat dengan Shogun. Sebagai seorang samurai sejati, Lord Asano memegang teguh ajaran bushido untuk tidak memberi suap kepada siapa pun sebagai sebuah sikap yang terhormat dari seorang samurai. Untuk menjaga nama baik dan reputasi seorang samurai, Lord Asano bersikukuh menolak memberi suap kepada Kira.

"Dalam acara yang khidmat seperti ini, memberi lebih dari yang seharusnya pada pemimpin Upacara adalah tindakan yang rendah. Aku menolak untuk merendahkan diriku seperti itu. Semua penasihat setuju..." (hal. 31)

Sebagai samurai Jepang, para pengikut Lord Asano sangat memegang teguh ajaran bushido dan mereka bangga bisa membalas dendam atas kematian majikan mereka sesuai dengan ajaran bushido yang mereka anggap sebagai bentuk sikap moral tertinggi seperti kutipan berikut.

\section{"Pada akhirnya, hanya nama yang akan hidup untuk}

Jurnal Ilmiah Bahasa dan Sastra

ISSN : 23557083

Volume 2 Nomor 1 Juni 2015

selamanya. Para samurai Ako dengan berani menentang undang-undang Shogun. Mereka rela mati demi pemimpinnya, untuk menunjukkan pengabdian pada apa yang mereka anggap sikap moral tertinggi” (hal. 311)

\section{KESIMPULAN DAN SARAN}

\section{Kesimpulan}

Ajaran Bushido yang merupakan pedoman bagi samurai banyak mengajarkan mengenai kepatuhan, pengabdian serta kesetiaan dalam mengabdi. Bushido adalah ajaran yang terdapat pada Budha Zen, yang dapat diartikan sebagai kode etik para samurai. Kode etik ini meliputi kepatuhan, kesetiaan, tanggung jawab, kesederhanaan serta keberanian untuk mati. Kepercayaan terhadap Reinkarnasi atau keyakinan bahwa orang yang telah meninggal akan terlahir kembali, menjadikan samurai tidak pernah takut menghadapi kematian. Pengabdian kesetiaan samurai melebihi batas antara hidup dan mati.

Contoh kesetiaan samurai kepada majikannya yang terdapat pada kisah 47 Ronin. Kisah 47 Ronin adalah cerita mengenai pembalasan dendam mantan samurai atas kematian majikan mereka. 
Kisah ini terjadi di wilayah Akou di Jepang. Kisah pembalasan dendam para Ronin dilakukan untuk membalaskan dendam majikan mereka yang telah meninggal. Balas dendam ini dilakukan karena Kira Kozuke No Suke, sebagai pejabat Koke telah melukai Asano Takumi. Balas dendam Ronin merupakan pengabdian kepatuhan mereka terhadap Asano Takumi Naganori. Ini dikarenakan Asano adalah majikan para Ronin. Balas dendam Ronin dipimpin oleh Oishi Kuranosuke Yoshitaka adalah kepala samurai klan Asano. Maka balas dendam Ronin dipimpin oleh Oishi. Oishi dan anak buahnya memenggal kepala Kira dan meletakkan kepala musuh majikan mereka di atas makam Asano. Balas dendam yang dilakukan mereka telah berhasil. Setelah berhasil melakukan balas dendam para Ronin melakukan Junshi. Hal ini dilakukan untuk mengikuti kematian Asano. Perilaku Junshi yang dilakukan ke 47 Ronin adalah sikap pertanggung jawaban dan keberanian untuk membuktikan kesetiaan para Ronin kepada Asano. Junshi adalah tradisi sejarah pada zaman Chinese Wei (Weizhi) pada abad 646. Pada zaman ini banyak samurai dan pelayan yang membunuh dirinya ketika majikan mereka meninggal.

Nilai Kesetiaan bushidou masyarakat feodal di Jepang lahir bersamaan dengan lahirnya sistem wilayah yang dikelola oleh kizoku, dimana feodalisme merupakan penguasaan lahan tanah yang terpecah belah sebagai faktor produksi melalui kekuatan militer. Pada zaman feodal di Jepang bushido merupakan konsep pengabdian diri bushi. Di dalam ajaran bushido terdapat nilai-nilai kejujuran, kesopanan, kesetiaan, kehormatan, kebajikan dan keteguhan hati. Pada awalnya konsep pengabdian diri bushi disebut dengan bushido yang ditandai dengan pengabdian diri yang mutlak dari anak buah terhadap tuannya, sehingga anak buah melakukan junshi yaitu bunuh diri mengikuti kematian tuannya. Namun pada zaman Edo Tokugawa konsep bushido diubah menjadi shido dimana kesetiaan bushi terhadap tuan diubah menjadi kesetiaan kepada shogun.

Bushi merupakan golongan masyarakat birokrat pada zaman Edo. Sejarah bushi sangat identik dengan sejarah feodalisme di Jepang, karena bushi itu sendiri lahir dari fungsinya 
sebagai pengawas di daerah pertanian yang pada mulanya mereka adalah petani, tetapi mereka dipersenjatai untuk menjalankan fungsi keamanan di dalam wilayah tuannya. Kesetiaan menjadi bagian dari sejarah peradaban bangsa Jepang sejak zaman samurai sampai zaman modern. Kesetiaan merupakan sifat yang dimiliki oleh bangsa Jepang yang telah membudaya, yang muncul dari adanya rasa solidaritas sehingga menimbulkan rasa kebersamaan dalam kehidupan sosial. Kesetiaan adalah kesediaan melaksanakan perintah atau keinginan orang lain dengan mengorbankan kepentingan pribadi. Kesetiaan merupakan wujud balas budi seseorang terhadap budi baik orang lain. Bagi orang Jepang budi baik orang lain disebut on dan balasannya disebut dengan onegashi. Seluruh kewajiban membalaskan budi baik tersebut disebut dengan giri.

Kesetiaan secara umum dibagi menjadi tiga unsur yaitu, setia karena situasi yang terdesak atau terpaksa, setia karena ajaran (moral), dan setia untuk mendapat keuntungan. Kesetiaan merupakan sifat yang harus dimiliki oleh seorang samurai. Kesetiaan untuk kepentingan bersama dan tuannya merupakan pemenuhan kewajiban samurai untuk mentaati nilai-nilai bushido. Keberhasilan masyarakat Jepang dalam perekonomian sekarang ini, juga dikarenakan sifat mereka yang loyal terhadap perusahaan tempat mereka bekerja. Karena besarnya rasa loyalitas yang dimiliki oleh orang Jepang, mereka rela bekerja keras untuk kemajuan perusahaannya. Budaya malu yang ada dalam masyarakat Jepang merupakan ketidakmampuan membalaskan budi baik orang lain, sehingga mereka harus membalaskan budi baik orang lain. Karena bagi masyarakat Jepang mereka lebih mengutamakan penilaian dari masyarakat dari pada rasa takut.

\subsection{Saran}

Keadaan sejarah peristiwa 47 Ronin yaitu pada zaman Edo. Penelitian yang banyak memfokuskan pada keadaan sejarah peristiwa 47 ronin diharapkan dapat menambah pengetahuan mengenai kehidupan sejarah masyarakat Jepang pada zaman Edo.

Selain itu penelitian perilaku Junshi para samurai dapat dijadikan 
sebagai wawasan pengetahuan dalam hal kepahlawanan yang ada di Jepang. Perilaku Junshi para tokoh cerita dalam Novel Kisah 47 Ronin Karya John Allyn berakhir dengan kematian ke 47 Ronin yang melakukan Junshi dengan cara Seppuku. Kesetiaan yang melebihi batas antara hidup dan mati dilakukan para samurai yang tidak mampu hidup tanpa majikan serta lebih baik mengikuti jalan kematian majikan agar tetap bisa mengabdi meskipun di alam akhirat.

\section{DAFTAR PUSTAKA}

Takie Sugiyama Lebra. 1974. "Reciprocity and Asymmetric Principle: An Analytical Reappraisal of the Japanese Concept of On".

Harumi Befu. 1998. Japan: an Anthropological Introduction.

Benedict. 1992. Japanese Society.

Nurgiyantoro, Burhan. 1998. Teori Pengkajian Fiksi. Yogyakarta: Gadjah Mada University Press. 